\title{
PERFORMANCE RATING AND YARDSTICK COMPETITION IN SOCIAL SERVICE PROVISION
}

\author{
FEDERICO REVELLI
}

CESIFO WORKING PAPER NO. 1270

CATEgORY 1: Public FinANCE

SEPTEMBER 2004

PRESENTED AT TAPES CONFERENCE ON FISCAL FEDERALISM

MAY 2004

- from the CESifo website: www.CESifo.de 


\title{
PERFORMANCE RATING AND YARDSTICK COMPETITION IN SOCIAL SERVICE PROVISION
}

\begin{abstract}
This paper investigates whether national evaluation of decentralised government performance tends, by lessening local information spill-overs, to reduce the scope for local performance comparisons and consequently to lower the extent of spatial auto-correlation among local government expenditures. It analyses UK local government expenditures on personal social services before and after the introduction of a national performance assessment system (SSPR, Social Services Performance Rating) that would attribute a rating to each local authority. The empirical evidence suggests that the introduction of the SSPR has substantially reduced policy mimicking among neighboring jurisdictions.
\end{abstract}

JEL classification: C21, H72, H77.

Keywords: social services, welfare competition, information spill-overs, spatial autocorrelation.

\author{
Federico Revelli \\ Department of Economics \\ University of Torino \\ Via Po 53 \\ 10124 Torino \\ Italy \\ federico.revelli@unito.it
}




\section{Introduction}

The past decade has witnessed a surge of empirical research on strategic interaction among local governments in the setting of tax rates, ${ }^{1}$ expenditures on public services, ${ }^{2}$ and standards and regulatory measures. ${ }^{3}$

In particular, a strand of the literature has explored the issue of welfare competition. ${ }^{4}$ In the presence of welfare recipients' mobility, decentralised welfare policies would be set strategically, in the sense that an authority would look to neighboring jurisdictions' benefit levels before setting its own to avoid becoming a "welfare magnet," and would respond to the policies enacted by its neighbors, leading to a race to the bottom and a possible erosion of the welfare state (Sinn [48]).

The existing empirical literature on decentralised welfare policy setting typically uses US state data and relies on the race to the bottom notion. ${ }^{5}$ It tests for inter-state welfare competition, by estimating a reduced-form reaction function where the benefit level in a state is related to a weighted average of neighboring states' benefit levels. ${ }^{6}$

As far as EU countries are concerned, while it is rarely the case that welfare policies are set in a decentralised way - with most redistributive policies being decided at the national level, - still in several instances local authorities provide social services that affect the well-being of the poor.

In the UK, for instance, while the bulk of welfare policies is set at the

\footnotetext{
${ }^{1}$ Ladd [36], Besley and Case [8], Case [21], Heyndels and Vuchelen [32], Brett and Pinkse [14], Brueckner and Saavedra [18], Buettner [19], Revelli [39], Bordignon et al. $[12]$.

${ }^{2}$ Case et al. [22], Kelejian and Robinson [35], Murdoch et al. [38], Bivand and Szymanski [10], [11], Revelli [41], [42], Baicker [5].

${ }^{3}$ Brueckner [15], Fredriksson and Millimet [30], [31].

${ }^{4}$ Smith [49], Shroder [47], Smith [50], Rom et al. [43], Figlio et al. [29], Saavedra [44], Wheaton [53], Bailey and Rom [6], Berry et al. [7].

${ }^{5}$ Brueckner [16] reviews the empirical welfare competition literature.

${ }^{6}$ Shroder [47] and Berry et al. [7] represent exceptions, in that they estimate structural models including a benefit setting equation and a recipiency ratio (poverty rate) determination equation.
} 
national level (minimum income guarantee, jobseeker's allowance and housing benefits), yet local authorities devote a share of total revenues to social expenditures, in terms of care and assistance to the elderly, help to families and children with social needs, as well as a number of services to people with disabilities and health needs (Social Services Inspectorate [51]).

In financial year $2000 / 2001,{ }^{7}$ English local authorities spent over $£ 10$ billion on personal social services, corresponding to $20 \%$ of total local spending and amounting to almost half of expenditure on education (CIPFA [23]). While most of the above social services do not typically take the form of a money transfer to the poor, still they mainly benefit low-income households, in that the need for social services tends to be correlated with income deprivation (Department of the Environment, Transport and the Regions [28]).

An interesting feature of local spending on personal social services in the $\mathrm{UK}$ is that it shows positive spatial auto-correlation, in the sense that the policies of nearby localities - that is, of localities sharing a border - appear to be more correlated than those of far-away ones. For instance, in financial year 2000/2001 the standard measure of spatial dependence, the Moran statistic (Anselin [1]), definitely rejects the hypothesis that the location of an authority does not affect its social service provision policy. ${ }^{8}$

This paper aims at exploring the causes of such spatial auto-correlation. In the light of the welfare competition literature cited above, one could wonder whether the spatial pattern in social spending in the UK is the outcome of a similar sort of competition. However, the mobility of the beneficiaries of personal social services is likely to be rather low, virtually ruling out the

\footnotetext{
${ }^{7}$ In the UK, the financial year starts on 1st April and ends on 31st March.

${ }^{8}$ The Moran test is a sort of spatial Durbin-Watson statistic that represents a measure of the similarity in value (covariance) and association in space (contiguity). It is asymptotically normally distributed under the null hypothesis of absence of spatial auto-correlation (Anselin [1]). When computed on a raw measure of social service provision across the 146 English local authorities providing social services (the level of social expenditure per beneficiary), the Moran test yields a value of 0.68 , with a standard normal value of 16.8 , meaning that one can confidently reject the null of no spatial auto-correlation.
} 
race to the bottom hypothesis.

On the other hand, it can be argued that a spatial pattern in social expenditures might arise from the existence of a local "informational" externality, even in the absence of the threat of welfare-induced migration. The idea is that information about local public service provision in the neighborhood is both relevant - because neighboring jurisdictions face a similar socio-economic environment and are likely to experience similar shocks - and easily available, because it naturally tends to spill over into adjacent jurisdictions (Besley and Case [8]). As a result, the local information spill-over would make it possible for imperfectly informed citizens to improve politicians' selection, by evaluating the performance of their own government relative to the performances of governments in nearby localities (Case [21]).

Furthermore, as well as affecting selection, comparative performance evaluation would also affect politicians' discipline: as a result of the spill-over from neighboring jurisdictions, officials would exert more effort in order to enhance their performance relative to their neighbors. The discipline effect of comparative performance evaluation would therefore generate a sort of "yardstick competition" among local authorities, with officials mimicking the behavior of nearby governments. ${ }^{9}$

The main objective of this paper is to ascertain whether the observed spatial pattern in local welfare spending in the UK can indeed be attributed to the discipline effect of yardstick competition, or if it can alternatively be explained either by welfare competition or by the fact that neighboring authorities are hit by correlated shocks (Manski [37]).

In order to accomplish this aim, this paper exploits the institutional change that occurred in the UK in October 2001, when the Department of Health (DoH) announced the introduction of a system of Social Services Performance Rating (SSPR). The SSPR would produce every year, starting

\footnotetext{
${ }^{9}$ The idea of yardstick competition in a political agency framework was first put forward by Ladd [36], Case [21] and Case et al. [22], and formalised by Besley and Case [8].
} 
from May 2002, a statistical overview of the performance and rating of each council on a zero to three stars scale, based on the full range of available evidence in the previous financial year.

The interesting aspect of the SSPR is that its objective is "to ensure that social care issues are properly addressed, to promote good practice and to identify councils that are performing poorly (...) The ratings are intended to improve public information about the current performance of services (...) People have a right to know how well their councils are performing in meeting these responsibilities, whether they are receiving such services themselves, have a family member receiving such services, or are a council tax payer."10

If the main objective of the SSPR is to improve public information about local government performance in social service provision, then it could be argued that the mimicking effect arising from local information spill-overs should play a less important role after its introduction. In the presence of a national system of performance evaluation, the relevance of the performances of neighboring authorities decreases, since information is made easily available on nation-wide practice in social service provision. Consequently, analysing the degree of spatial auto-correlation in welfare spending before and after the introduction of the SSPR should allow us to conclude whether yardstick competition was indeed responsible for the observed spatial pattern.

The rest of the paper is organised as follows. Section 2 presents a simple model of the determination of local spending on personal social services, and section 3 discusses the econometric issues involved in empirically implementing it. Section 4 presents the estimation results, based on data for the 146 UK local governments that provide social services. Finally, section $\mathbf{5}$ provides some further testing of the yardstick competition hypothesis, section 6 explores whether the political complexion of local jurisdictions can help explain their policy-making processes and spatial interaction patterns, and

\footnotetext{
${ }^{10}$ Social Services Inspectorate [51].
} 
section 7 concludes.

\section{A model of social service provision}

\subsection{Model set-up}

Consider a set of $N$ local jurisdictions. In each jurisdiction $i$ live $g_{i}$ identical individuals that have zero income and own no property, and $h_{i}$ identical individuals earning (exogenous) income $q_{i}$ and owning property of value $b_{i}$. Total population in the jurisdiction is: $p_{i}=g_{i}+h_{i}$.

The government in each jurisdiction is in charge of providing social services. The $g_{i}$ non-taxpayers directly benefit from expenditures on social services, that are funded by the property taxes paid by the $h_{i}$ taxpayers. While it is reasonable to think that taxpayers represent the majority of the resident population $\left(h_{i}>g_{i}\right)$, and do not directly benefit from social spending (but rather pay its cost), still there are a number of reasons why they could favour social expenditure. ${ }^{11}$

The taxpayer's utility - equation (1) - depends on her own private consumption $\left(y_{i}\right)$ and on the indirect benefits she receives from social expenditure $\left(s_{i}\right)$, with $\mathbf{c}_{i}$ representing a vector of $J$ community characteristics:

$$
u_{i}=u\left(y_{i}, s_{i} ; \mathbf{c}_{i}\right)
$$

Denoting by $x_{i}$ and $m_{i}$ the levels of per capita social expenditures and per capita (lump-sum) central government grants, and assuming that the local government budget constraint must be balanced, the taxpayer's budget constraint can be expressed as: ${ }^{12}$

$$
y_{i}=q_{i}-\tau_{i}\left(x_{i}-m_{i}\right)
$$

where: $\tau_{i}=\frac{p_{i}}{h_{i}}$ is the tax price of local public spending on social services.

\footnotetext{
${ }^{11}$ For a discussion of those theories, see Smith [50] and Shroder [47].

${ }^{12}$ The hypotheses of a local property tax, a balanced budget and lump-sum grants reflect the institutional features of the UK system of local government finance.
} 
As for the benefit taxpayers get from social expenditure, it is reasonable to assume (along with most of the welfare competition literature) that it depends on social spending per beneficiary, that is total social expenditure $\left(X_{i}\right)$ divided by the number of beneficiaries $\left(g_{i}\right)$ :

$$
s_{i}=\frac{X_{i}}{g_{i}}
$$

Given equations (2) and (3) above, the budget constraint can be rewritten as:

$$
y_{i}=\widetilde{q}_{i}-r_{i} s_{i}
$$

where: $\widetilde{q}_{i}=q_{i}+\tau_{i} m_{i}$ is "full" income including central government grants and $r_{i}=\frac{g_{i}}{h_{i}}$ equals the usual recipiency ratio (Shroder [47]).

Utility maximisation subject to the budget constraint yields a demand function for social services $\left(s_{i}\right)$ that, following the common practice in applied local public economics, can be written in log-linear form as:

$$
\ln \left(s_{i}\right)=\sum_{j=1}^{J} \alpha_{j} \ln \left(c_{i j}\right)+\lambda_{q} \ln \left(\widetilde{q}_{i}\right)+\lambda_{r} \ln \left(r_{i}\right)+\varepsilon_{i}
$$

where $\lambda_{q}$ is the income elasticity, $\lambda_{r}$ is the price (recipiency ratio) elasticity and $\varepsilon_{i}$ is a random term.

\subsection{Local interaction in social policy making}

In the presence of a decentralised welfare system and welfare recipients' mobility, the recipiency ratio in each jurisdiction would be determined endogenously, in that it would depend on social service provision in jurisdiction $i\left(s_{i}\right)$ as well as on social service provision in nearby jurisdictions. Following the spatial econometrics literature (Anselin [1]) as well as the recent empirical works on local strategic interaction (Brueckner [17]), assume that the effect on jurisdiction $i$ of the welfare policies enacted in the neighborhood can be expressed as a spatially weighted average of neighboring jurisdictions' expenditures, with non-stochastic weights $w_{i n}>0$ for adjacent (border sharing) 
jurisdictions $i$ and $n(i, n=1, \ldots, N) .{ }^{13}$ Using again a log-linear specification, the recipiency ratio can be expressed as:

$$
r_{i}=s_{i}^{\gamma_{s}}\left(\prod_{n} s_{n}^{w_{i n}}\right)^{\gamma_{-s}}
$$

where $\gamma_{s}>0$ and $\gamma_{-s}<0$. After taking logarithms, equation (6) is an expression similar to equation (13) in Shroder [47].

Replacing the expression for the recipiency ratio in equation (5), one obtains a reduced form reaction function that expresses a first-order spatial auto-correlation process in $s_{i}$ with parameter $\beta_{-s}$ :

$$
\ln \left(s_{i}\right)=\sum_{j=1}^{J} \beta_{j} \ln \left(c_{i j}\right)+\beta_{q} \ln \left(\widetilde{q}_{i}\right)+\beta_{-s}\left[\sum_{n=1}^{N} w_{i n} \ln \left(s_{n}\right)\right]+\varepsilon_{i}
$$

where:

$$
\beta_{j}=\frac{\alpha_{j}}{1-\lambda_{r} \gamma_{s}} ; \beta_{q}=\frac{\lambda_{q}}{1-\lambda_{r} \gamma_{s}} ; \beta_{-s}=\frac{\lambda_{r} \gamma_{-s}}{1-\lambda_{r} \gamma_{s}}
$$

Equation (7) is commonly estimated in the empirical welfare competition literature, where a non-zero estimate of parameter $\beta_{-s}$ is taken as evidence of welfare competition. Unfortunately, though, spatial auto-correlation in local expenditures is compatible with alternative theoretical explanations. Yardstick competition arising from a local information spill-over is one of them (Bordignon et al. [12]).

The basic idea underlying yardstick competition is that voters are imperfectly informed about the actual cost required for providing public services, and policymakers are heterogeneous with respect to efficiency in public service provision, in the sense that some politicians are more prone to waste resources or to divert public revenues to private aims. ${ }^{14}$

\footnotetext{
${ }^{13}$ Some recent literature on local strategic interaction - starting from Case et al. [22] argues that local jurisdictions might regard as neighbors other jurisdictions that, while not being geographically close, share common characteristics such as income level or demographic structure. I explore in section 6 below the role of similarity in political complexion.

${ }^{14} \mathrm{~A}$ formal model of yardstick competition in a political agency framework, that allows policymakers to be either Pigouvian welfare-maximisers or self-interested Leviathan, is in Besley and Case [8] and Besley and Smart [9]. Bordignon et al. [13] discuss the selection and discipline effects of yardstick competition, under different hypotheses about the information sets of principals (voters) and agents (policy-makers).
} 
In a decentralised system of government, though, it is possible for imperfectly informed voters to improve selection of politicians, by evaluating the efficiency of their own government relative to governments in nearby localities. Moreover, as a result of the information spill-over from neighboring jurisdictions, officials would exert more effort in order to enhance their performance relative to their neighbors, and would end up mimicking the policies of nearby governments (Besley and Case [8]).

The discipline effect of comparative performance evaluation can be introduced into equation (5) by allowing the level of spending in jurisdiction $i$ to be affected by a measure of expenditures in nearby localities: $c_{i 1}=\prod_{n} s_{n}^{w_{i n}}$, where $w_{i n}$ are positive non-stochastic weights on neighboring jurisdictions' expenditures (Case et al. [22]). Positing now that the recipiency ratio $r$ is exogenous, equation (5) can be expressed as:

$$
\ln \left(s_{i}\right)=\sum_{j=2}^{J} \alpha_{j} \ln \left(c_{i j}\right)+\lambda_{q} \ln \left(\widetilde{q}_{i}\right)+\lambda_{r} \ln \left(r_{i}\right)+\alpha_{1}\left[\sum_{n=1}^{N} w_{i n} \ln \left(s_{n}\right)\right]+\varepsilon_{i}
$$

Equation (9) formalises the idea that a government can afford to set high expenditures if its neighbors select high spending levels - as the information spill-over conveys in that case the signal of a high cost of social services due to exogenous factors over which politicians have no control - while it will be forced to set low expenditure levels if neighbors' expenditures are low. Hence, the spending level in a jurisdiction will tend to be positively correlated $\left(\alpha_{1}>0\right)$ with the expenditures in the neighborhood. ${ }^{15}$

Clearly, since both equation (7) and equation (9) include a spatial lag of the dependent variable $\left(\sum_{n=1}^{N} w_{i n} \ln \left(s_{n}\right)\right)$ among the explanatory variables, it is not possible to discriminate between a welfare competition model and

\footnotetext{
${ }^{15}$ It has been argued (Besley and Case [8], Bordignon et al. [12]) that, if voters knew the non-stochastic determinants of local expenditures in own and neighboring jurisdictions, yardstick competition would yield correlation only among the unpredicted components of local expenditures - that is the residual $\varepsilon_{i}$ in equation (9). However, while we leave it to the data to reveal the information set of voters, it seems likely that - at least in the social services domain - voters are better informed about the overall burden of social expenditure than about its stochastic versus non-stochastic determinants.
} 
a yardstick competition model by means of estimation of a spatial reaction function only.

While, as argued above, the features of the UK system of welfare make a migration-induced race to the bottom unlikely, still this paper provides a way to discriminate among the two theories, by analysing the impact of the introduction of the national performance assessment system on local interaction patterns.

If spatial auto-correlation were due to welfare competition - parameter $\beta_{-s}$ in equation (7) - then the introduction of the national performance assessment system should have no effect on it, because it does not affect the incentives for local authorities to compete with their neighbors to avoid inmigration of welfare recipients.

On the other hand, if local information spill-overs were responsible for the observed spatial auto-correlation in social spending - parameter $\alpha_{1}$ in equation (9) - then one should observe less spatial auto-correlation after the introduction of the performance assessment system based on uniform national standards.

\section{Empirical implementation}

Turning to estimation of a spatial reaction function such as (9), standard methods - OLS (ordinary least squares) - are biased because own and neighbors' spending levels are determined simultaneously (Anselin [1]). Moreover, the presence of a spatial process in the error term could give the wrong impression of strategic interaction, even if none is really occurring (Brueckner $[15])$.

To see how estimation is carried out, consider equation (10) below - the matrix form analogue of (9) - expressing a SAR (spatial auto-regressive) process in the dependent variable:

$$
\mathbf{s}=\mathbf{C} \boldsymbol{\alpha}_{-1}+\lambda_{q} \widetilde{\mathbf{q}}+\lambda_{r} \mathbf{r}+\alpha_{1} \mathbf{W} \mathbf{s}+\boldsymbol{\varepsilon}
$$


where $\mathbf{W}$ is the row-standardised $(N \times N)$ matrix of spatial weights $w_{\text {in }}$. $\mathbf{C}$ is a $(N \times(J-1))$ matrix of exogenous variables, $\boldsymbol{\alpha}_{-1}$ is a $((J-1) \times 1)$ vector of parameters to be estimated, $\widetilde{\mathbf{q}}$ and $\mathbf{r}$ - representing income and recipiency ratio respectively - are $(N \times 1)$ vectors, and all variables are in logarithm.

The well-known econometric problem that arises in the estimation of equation (10) consists in separately identifying parameter $\alpha_{1}$, expressing an endogenous interaction effect, and a potential spatial process in the error term $\varepsilon$ :

$$
\varepsilon=\rho \mathbf{W} \boldsymbol{\eta}+\boldsymbol{\eta}
$$

where the $(N \times 1)$ vector of error terms $\varepsilon$ is allowed to have a SMA (spatial moving average) structure with parameter $\rho$, with $|\rho|<1$, while $\boldsymbol{\eta}$ is a $(N \times 1)$ vector of innovations, with $E\left(\boldsymbol{\eta} \boldsymbol{\eta}^{\prime}\right)=\sigma_{\eta}^{2} \mathbf{I}$.

The identification problem is due to the fact that the spatial processes in (10) and (11) tend to mimic each other, so that the presence of correlated shocks might be mistaken for an endogenous interaction effect (Case [20]) ${ }^{16}$

Basically, two approaches exist for getting consistent estimates of the spatial parameter $\alpha_{1}$ in (10). The first one is based on an IV (instrumental variables) principle, and consists in finding variables that are correlated with neighbors' endogenous variable (Ws), while not being correlated with $\varepsilon .{ }^{17}$ IV is based on the idea of removing the bias-generating correlation between the endogenous regressor Ws and the error term $\varepsilon$ (Kelejian and Prucha [34]):

$$
E\left[(\mathbf{W} \mathbf{s}) \boldsymbol{\varepsilon}^{\prime}\right]=\mathbf{W}\left(\mathbf{I}-\alpha_{1} \mathbf{W}\right)^{-1}(\mathbf{I}+\rho \mathbf{W})(\mathbf{I}+\rho \mathbf{W})^{\prime} \sigma_{\eta}^{2} \neq 0
$$

Estimation is performed by regressing $\mathbf{s}$ on the matrix $[\mathbf{Z}, \widehat{\mathbf{W}} \mathbf{s}]$, where $\mathbf{Z}=[\mathbf{C}, \widetilde{\mathbf{q}}, \mathbf{r}]$ and $\widehat{\mathbf{W}} \mathbf{s}$ is the predicted value of neighbors' expenditures from a first stage regression of Ws on the matrix of own and neighbors' exogenous

\footnotetext{
${ }^{16}$ The same holds for a spatial auto-regressive error term (Anselin [1]).

${ }^{17}$ Examples of estimation of spatial reaction functions based on IV methods are Ladd [36], Figlio et al. [29], Buettner [19] and Fredriksson and Millimet [30], [31].
} 
variables $[\mathbf{Z}, \mathbf{W Z}]$ (Kelejian and Robinson [35]). Since neighbors' spending is instrumented, the 2SLS (two-stage least squares) estimate of $\alpha_{1}$ is consistent, because it is not affected by potential correlated shocks experienced by neighbors (Besley and Case [8]). Moreover, the IV approach has the advantage of allowing us to control for potential endogeneity of further r.h.s. variables in (10), such as the recipiency ratio. ${ }^{18}$

The second approach is based on an ML (maximum likelihood) principle and consists in inverting the spatial reaction function (10) (Case et al. [22]):

$$
\mathbf{s}=\left(\mathbf{I}-\alpha_{1} \mathbf{W}\right)^{-1} \mathbf{Z} \boldsymbol{\delta}+\left(\mathbf{I}-\alpha_{1} \mathbf{W}\right)^{-1} \boldsymbol{\varepsilon}
$$

with: $\mathbf{Z}=[\mathbf{C}, \widetilde{\mathbf{q}}, \mathbf{r}]$ and $\boldsymbol{\delta}^{\prime}=\left[\boldsymbol{\alpha}_{-1}^{\prime}, \lambda_{q}, \lambda_{r}\right]$. ML is more efficient, because it allows us to control for the spatial process in the error term explicitly. In fact, the full model represented by equations (10) and (11) - known as a SARMA (Spatial Auto Regressive Moving Average) - can be inverted and estimated by ML, by exploiting the properties of the well behaved error vector $\boldsymbol{\eta}$ (Anselin and Florax [3]): ${ }^{19}$

$$
\mathbf{s}=\left(\mathbf{I}-\alpha_{1} \mathbf{W}\right)^{-1} \mathbf{Z} \boldsymbol{\delta}+\left(\mathbf{I}-\alpha_{1} \mathbf{W}\right)^{-1}(\mathbf{I}+\rho \mathbf{W}) \boldsymbol{\eta}
$$

with log-likelihood function:

$$
L=c_{\pi}-\frac{N}{2} \ln \left(\sigma_{\eta}^{2}\right)-\ln \left|\mathbf{J}_{\rho}\right|+\ln \left|\mathbf{J}_{\alpha}\right|-\frac{1}{2 \sigma_{\eta}^{2}}\left(\mathbf{J}_{\alpha} \mathbf{s}-\mathbf{Z} \boldsymbol{\delta}\right)^{\prime}\left(\mathbf{J}_{\rho} \mathbf{J}_{\rho}^{\prime}\right)^{-1}\left(\mathbf{J}_{\alpha} \mathbf{s}-\mathbf{Z} \boldsymbol{\delta}\right)
$$

where $c_{\pi}$ is a constant, and $\left|\mathbf{J}_{\rho}\right|=|\mathbf{I}+\rho \mathbf{W}|$ and $\left|\mathbf{J}_{\alpha}\right|=\left|\mathbf{I}-\alpha_{1} \mathbf{W}\right|$ are the Jacobian terms of the transformation between $\boldsymbol{\eta}$ and $\mathbf{s}$ (Anselin [2]).

\footnotetext{
${ }^{18}$ According to the welfare competition hypothesis, the recipiency ratio would be determined endogenously, and would consequently lead to biased estimates of the crucial spatial parameter $\alpha_{1}$.

${ }^{19}$ On the other hand, ML estimation poses serious identification problems in a model that has a first-order spatial auto-regressive process in the dependent variable - equation (10) - with a first-order spatial auto-regressive process in the error term: $\varepsilon=\lambda \mathbf{W} \boldsymbol{\varepsilon}+\boldsymbol{v}$ (see in particular Anselin [1], pp. 87-88). For GMM (Generalised Method of Moments) estimation and testing of a spatial auto-regressive model with spatial auto-regressive disturbances, see Kelejian and Prucha [34] and Saavedra [44], [45].
} 
In order to learn about the relative importance of the two spatial processes driven by parameters $\alpha_{1}$ and $\rho$ respectively, and in particular to ascertain whether the introduction of the performance assessment system has affected the spatial interaction pattern in social expenditures, the next section shows estimates of the spatial reaction function that are based on IV and ML principles, both before and after the introduction of the ratings system.

\section{Data and estimation results}

I first estimate the social spending reaction function on the cross-sections of 146 local authorities in England in financial years 2000/2001 and 2003/2004, that is before and after the introduction of the SSPR. ${ }^{20}$

The data set includes all English authorities providing personal social services, namely 32 boroughs of the London metropolitan area, 36 metropolitan districts of the other five metropolitan areas, 44 non metropolitan unitary authorities, and 34 non metropolitan upper tier authorities (counties) in two-tier areas. To account for potential institutional differences among those authorities, the reaction function includes authority type dummies. Descriptive statistics and data sources of all the variables used in the analysis are reported in tables 1 and $2 .^{21}$

The dependent variable is computed as total expenditure on personal social services in a jurisdiction, divided by the number of income deprived residents as a proxy for the number of users of social services. While the SSPR is based upon and is intended to improve the quality of social service provision - that might not necessarily be correlated with the level of expenditure - the hypothesis we wish to test here is whether local authorities react to the

\footnotetext{
${ }^{20}$ The SSPR went through a two-year transition period, as it was announced during financial year 2001/2002, and implemented throughout financial year 2002/2003, when the first star ratings were released.

${ }^{21}$ The 146 authorities cover the whole of England and do not overlap in social service provision. Two authorities are excluded because of missing data (unitary authority of Swindon) or peculiar geographic location (unitary authority of Isle of Wight).
} 
introduction of the SSPR by changing their spending behavior.

The explanatory variables include central government lump-sum grants, residential property tax base per capita as a proxy for income (income data not being available at the local level), size and density of population, and the percentages of old and young residents over total population. The recipiency ratio is computed as the ratio of income deprived people to taxpayers.

However, if the recipiency ratio were in fact determined endogenously due to welfare competition, both the price elasticity and the spatial autoregressive coefficient would be estimated with a bias. Consequently, IV estimation of (10) uses variables reflecting the economic structure of a locality - proportion of properties that are not devoted to domestic use (commercial and industrial) and value of non-domestic property per capita - as instruments for the recipiency ratio. While the above variables are likely to reflect reasonably well the economic complexion of a jurisdiction and are highly correlated with the recipiency ratio, they can be reasonably thought of as changing sluggishly over time, and consequently being exogenous at least in the short run. ${ }^{22}$

The results for financial year 2000/2001 are shown in table 3, while the results for financial year 2003/2004 are shown in table $4 .^{23}$

First, the robust LM (Lagrange Multiplier) test developed by Anselin et al. [4] for an alternative hypothesis of a spatial lag - equation (10) - as well as the robust LM test for an alternative hypothesis of a spatial process in the error term - equation (11) - are shown in the lower panel of table 3. The LM tests definitely suggest that, in financial year 2000/2001 (before

\footnotetext{
${ }^{22}$ In theory, one could attempt to estimate a recipiency ratio determination equation such as (6) (as in Shroder [47]). However, since yearly data on the actual number of users of social services are not available and data on income deprived residents are from year 2000 only (Department of the Environment, Transport and the Regions [28]), it is not feasible to estimate the impact of own and neighbors' social service expenditures on local recipiency ratios.

${ }^{23}$ The equation also includes dummies according to the type of authority (London boroughs, metropolitan districts, unitary authorities, counties). As none of them turns out to be significant, though, they are not reported.
} 
the introduction of the performance assessment system), a spatial lag in the dependent variable is the most likely source of spatial dependence. The robust LM test for a spatial lag - that is distributed as a $\chi_{[1]}^{2}$ - takes on the value of 7.96 (the $\chi_{[1]}^{2}$ value at $p=0.99$ is 6.63 ), while the robust LM test for a spatial process in the error term is 0.01 . Moreover, the LR (likelihood ratio) test reported at the bottom of column 1 in table 3 allows us to confidently reject the restriction $\alpha_{1}=0$ that is imposed in a non-spatial model. ${ }^{24}$

The results of estimation of equation (10) - upper panel of table 3 - show strong and significant positive effects of grant and income on social spending (grant elasticity ranging from 0.57 to 0.62 and income elasticity ranging from 0.21 to 0.23 , depending on the specification), while the recipiency ratio turns out to have a highly significant negative effect on social expenditure per beneficiary. The OLS and ML estimates that treat the recipiency ratio as exogenous - columns 1, 2 and 4 in table 3 - and the IV estimate that uses exogenous structural characteristics of the jurisdiction as instruments, yield similar values - a price elasticity ranging from -0.15 to $-0.21 .^{25}$ On the other hand, the demographic variables do not have a significant impact, except for a positive effect of density of population.

Finally, the estimates of the crucial spatial parameters yield consistent results. The ML estimate of $\alpha_{1}$ in the SAR specification that does not allow for correlated errors - column 2 in table 3 - is 0.18 . As expected, it is lower than the OLS estimate of $\alpha_{1}$, because OLS does not control for simultaneity of own and neighbors' decisions. The IV estimate and the ML estimate of $\alpha_{1}$ that controls for a spatial pattern in the error term - columns 3 and 4

\footnotetext{
${ }^{24}$ Twice the difference between the log-likelihoods of the restricted and unrestricted models is distributed as a $\chi^{2}$ with degrees of freedom equal to the number of restrictions - number of spatial parameters set to zero (Anselin [1]).

${ }^{25}$ Moreover, when the residuals from a first stage regression of the recipiency ratio on the matrix of instruments are inserted into equation (10) as a regressor (a Hausman endogeneity test), the coefficient on the residuals is not estimated to be significantly different from zero $\left(F_{(1,134)}\right.$ test $\left.=2.8\right)$, suggesting that the recipiency ratio can be treated as exogenous in $(10)$.
} 
in table 3 - yield an elasticity of about 0.20 , while spatial dependence in the residuals (parameter $\rho$ ) is estimated to be negative, but not statistically significant. It is interesting to notice that the OLS bias turns out to be very small, suggesting that the upward OLS bias provoked by positive spatial autocorrelation in the dependent variable (the term $\mathbf{W}\left(\mathbf{I}-\alpha_{1} \mathbf{W}\right)^{-1}$ in equation (12)) is almost fully offset by the downward OLS bias determined by negative correlation in the residuals (the term $(\mathbf{I}+\rho \mathbf{W})(\mathbf{I}+\rho \mathbf{W})^{\prime} \sigma_{\eta}^{2}$ in equation (12)).

Turning to financial year 2003/2004, the results are shown in table 4 . If the auto-correlation that emerged in financial year 2000/2001 were due to yardstick competition arising from a local information spill-over, then we should expect to observe less of it after the introduction of the performance rating system.

The coefficient estimates for financial year 2003/2004 closely resemble the ones for financial year 2000/2001, with a large and significant positive effect of grant on expenditure (almost 0.8 ), a positive and significant income elasticity (0.2), and a negative and significant effect of the recipiency ratio (a price elasticity of about -0.1 ).

As far as local interaction is concerned, it turns out that spatial autocorrelation in social spending has dropped dramatically. The estimated size of the auto-regressive coefficient $\alpha_{1}$ falls from a value of 0.20 obtained for financial year 2000/2001 in table 3 to a value of 0.09 in 2003/2004 (table 4), and $\alpha_{1}$ is not estimated to be significantly different from zero any longer.

\section{Evaluating the impact of the SSPR}

Inspection of the results of estimation of the spatial reaction function on the cross-sections of $2000 / 01$ and $2003 / 04$ points to a noticeable change in the spatial pattern of social spending. In particular, the Moran test on the predicted residuals from a non spatial model $\left(\alpha_{1}=0\right)$ - that is distributed as a standard normal $z(0,1)$ - falls from 2.12 in 2000/01 to 0.37 in 2003/04, 
suggesting that the null hypothesis of no spatial auto-correlation can no longer be rejected. Moreover, the robust LM test for spatial lag dependence - that is distributed as a $\chi_{[1]}^{2}$ - falls from a value of 7.96 in financial year $2000 / 2001$ to a value of 2.58 in $2003 / 2004$ (the $\chi_{[1]}^{2}$ value at $p=0.95$ is 3.84 ), and the likelihood ratio test of a spatial lag model against a nonspatial specification - that again is distributed as a $\chi_{[1]}^{2}$ - drops from 9.42 in $2000 / 2001$ to 2.01 in 2003/2004, suggesting that the restriction $\alpha_{1}=0$ that would be imposed in a non-spatial specification cannot be rejected. In line with the test results, $\alpha_{1}$ is not estimated to be significantly different from zero in the latter cross-section.

In order to formally test the impact of the SSPR and to convince ourselves of the significance of the reduction in spatial auto-correlation, table 5 reports estimates of the spatial auto-regressive model in equation (10) on the pooled cross-sections of 2000/2001 through 2003/2004, while allowing the spatial interaction term to be different in the latter cross-section, when the SSPR is fully in operation.

The results in table 5 show that while the estimate of $\alpha_{1}$ is a highly significant positive value of about 0.15 , interacting the neighbors' variable with the SSPR dummy yields a large and significant negative effect $(-0.09)$. Moreover, the likelihood of a model that restricts $\alpha_{1}$ to be constant across the four waves is significantly lower than the likelihood of an unrestricted model that allows $\alpha_{1}$ to be different in the latter cross-section, with the LR test reported at the bottom of table 5 rejecting the restriction of a constant $\alpha_{1}$ at the $99 \%$ level of confidence. ${ }^{26}$

Overall, the above evidence consistently suggests that spatial correlation in local expenditures on social services has dropped considerably. In par-

\footnotetext{
${ }^{26}$ When estimation is performed on a model that allows for fixed jurisdiction effects, the estimates turn out to be considerably less precise - probably due to the fact that the time-series is short (4 years) and that one cross-section is lost in taking deviations from the mean. Still, the ML estimate of $\alpha_{1}$ is a large value of $0.24(t=2.69)$ and the coefficient on neighbors' spending interacted with the SSPR dummy is $-0.36(t=1.96)$.
} 
ticular, it supports the idea that, by spreading information on nation-wide practice in social service provision, the SSPR has diminished the relevance of local information spill-overs and weakened the incentives for local authorities to mimic the policies of neighboring jurisdictions.

\section{Politics}

The above analysis might be missing an important point, by disregarding the role of politics in the local expenditure determination process. In particular, it could be argued that local jurisdictions should be more strongly affected by the policies enacted by governments that are controlled by the same political party. For instance, taxpayers living in Labour controlled jurisdictions could more likely take the performances of other Labour governments (rather than Conservative or Liberal Democrat ones) as a benchmark against which to compare the performance of their own government.

Consequently, I re-estimated the social expenditure reaction function (10), both by including a political party dummy (Labour, Conservative or Liberal Democrat) to control for possible differences in social service provision policy due to ideology, and by using a spatial weights matrix where only neighboring governments controlled by the same political party are given a positive weight. ${ }^{27}$

Somewhat surprisingly, though, it comes out that the political control dummies are estimated to have no effect on expenditures on social services, in the sense that Labour governments do not set expenditure levels per beneficiary that are higher than Liberal Democrat or Conservative ones. Rather, the data tend to suggest that it is indeed more likely to find a Labour government in jurisdictions with high poverty rates: the correlation coefficient

\footnotetext{
${ }^{27}$ In particular, the politically-weighted neighborhood matrix is constructed in such a way that neighboring authorities are given a weight equal to 1 if they are controlled by the same political party, and 0 otherwise, and it is standardised by dividing each element of the matrix by the matrix row-sum (number of neighbors of the same political party).
} 
between the Labour government dummy and the poverty rate is almost 0.6, while the correlation coefficient between the Conservative government dummy and the poverty rate is -0.5 . However, after controlling for the price of social services to residents and the other local characteristics that are believed to affect social service provision (matrix $\mathbf{Z}=[\mathbf{C}, \widetilde{\mathbf{q}}, \mathbf{r}]$ ), Labour controlled authorities turn out to be no more generous than Conservative and Liberal Democrat governments.

Coherently with the above result, it comes out that spatial auto-correlation in expenditures is no stronger among jurisdictions that are controlled by the same political party than among jurisdictions controlled by different political parties. The results obtained by means of a politically weighted neighborhood matrix are in line with those obtained with a standard unweighted neighborhood matrix and suggest, perhaps surprisingly, that politics does not play a significant role in inter-governmental interaction in social service provision.

\section{Concluding remarks}

This paper has proposed a strategy for identifying yardstick competition, that is based upon the exploitation of an institutional change that occurred in the UK in 2001, with the introduction of a national system of social services performance rating (SSPR). Since the main objective of the SSPR consists in improving public information about local authority performance, it should reduce the importance of local information spill-overs, by making information on nation-wide practice in social service provision easily available.

The results for financial year 2000/01 - before the introduction of the SSPR - suggest that local jurisdictions tend to mimic the policies of their neighbors. In particular, the IV and ML estimates of the coefficient on the spatially lagged expenditure variable yield roughly the same elasticity of 0.20 , while spatial dependence in the residuals is estimated not to be 
significantly different from zero. On the other hand, when analysing the same expenditures after the SSPR was at work (2003/04), the test and estimation results show that spatial auto-correlation in social spending has decreased considerably and turns out not to be statistically significant any longer. The same results are obtained when the four available waves of data (2000/01 to 2003/04) are pooled, suggesting that the introduction of the rating system has significantly moderated the scope for policy mimicking.

The results in this paper represent just a first step in the analysis of the impact of national evaluation of decentralised government performance on spatial interactions among local jurisdictions. In particular, investigating how the release of nation-wide performance ratings affects the behavior and mimicking patterns of local authorities seems to represent a stimulating avenue for future research.

\section{Acknowledgements}

I would like to thank seminar participants in Roma, L'Aquila, Prague (59 ${ }^{\text {th }}$ IIPF Congress), Padova, CESifo Munich (TAPES 2004), and particularly Tim Besley, David Figlio, Luciano Greco, Jean Hindriks, Jim Hines, Francesco Lagona, Fabio Padovano and Jorn Rattso for helpful comments.

\section{References}

[1] L. Anselin, Spatial Econometrics: Methods and Models, Kluwer Academic, Dordrecht, 1988.

[2] L. Anselin, Rao's score test in spatial econometrics, Journal of Statistical Planning and Inference 97 (2001) 113-139.

[3] L. Anselin, R. Florax, Small sample properties of tests for spatial dependence in regression models: Some further results, in: L. Anselin, R. 
Florax (Eds.), New Directions in Spatial Econometrics, Springer, Heidelberg, 1995, pp. 21-74.

[4] L. Anselin, K. Bera, R. Florax, M. Yoon, Simple diagnostic tests for spatial dependence, Regional Science and Urban Economics 26 (1996) 77-104.

[5] K. Baicker, The spillover effects of state spending, Journal of Public Economics (2004) for thcoming.

[6] M. Bailey, M. Rom, Interstate competition in health and welfare programs, Working Paper \#19, Scholars in Health Policy Research Program, Georgetown University (2001).

[7] W. Berry, R. Fording, R. Hanson, Reassessing the "race to the bottom" in state welfare policy, Journal of Politics 65 (2003) 327-349.

[8] T. Besley, A. Case, Incumbent behavior: Vote seeking, tax setting and yardstick competition, American Economic Review 85 (1995) 25-45.

[9] T. Besley, M. Smart, Does tax competition raise voter welfare? unpublished manuscript, London School of Economics (2001).

[10] R. Bivand, S. Szymanski, Spatial dependence through local yardstick competition: Theory and testing, Economics Letters 55 (1997) 257-265.

[11] R. Bivand, S. Szymanski, Modelling the spatial impact of the introduction of compulsive competitive tendering, Regional Science and Urban Economics 30 (2000) 203-219.

[12] M. Bordignon, F. Cerniglia, F. Revelli, In search of yardstick competition: A spatial analysis of Italian municipality property tax setting, Journal of Urban Economics 54 (2003) 199-217. 
[13] M. Bordignon, F. Cerniglia, F. Revelli, Yardstick competition in intergovernmental relationships: theory and empirical predictions, Economics Letters 83 (2004) 325-333.

[14] C. Brett, J. Pinkse, The determinants of municipal tax rates in British Columbia, Canadian Journal of Economics 33 (2000) 695-714.

[15] J. Brueckner, Testing for strategic interaction among local governments: The case of growth controls, Journal of Urban Economics 44 (1998) 438467.

[16] J. Brueckner, Welfare reform and the race to the bottom: Theory and evidence, Southern Economic Journal 66 (2000) 505-525.

[17] J. Brueckner, Strategic interaction among governments: An overview of empirical studies, International Regional Science Review 26 (2003) 175-188.

[18] J. Brueckner, L. Saavedra, Do local governments engage in strategic property tax competition? National Tax Journal 54 (2001) 203-229.

[19] T. Buettner, Local business taxation and competition for capital: the choice of the tax rate, Regional Science and Urban Economics 31 (2001) 215-245.

[20] A. Case, Spatial patterns in household demand, Econometrica 59 (1991) 953-965.

[21] A. Case, Interstate tax competition after TRA86, Journal of Policy Analysis and Management 12 (1993) 136-148.

[22] A. Case, J. Hines, H. Rosen, Budget spillovers and fiscal policy interdependence, Journal of Public Economics 52 (1993) 285-307. 
[23] CIPFA, Finance and General Statistics 2000-01, Chartered Institute of Public Finance and Accountancy, London, 2000.

[24] CIPFA, Finance and General Statistics 2003-04, Chartered Institute of Public Finance and Accountancy, London, 2003.

[25] CIPFA, Local Government Comparative Statistics, Chartered Institute of Public Finance and Accountancy, London, 2000.

[26] Department of the Environment, Transport and the Regions, Local Government Financial Statistics, UK Government, London, 2000.

[27] Department of the Environment, Transport and the Regions, Local Government Financial Statistics, UK Government, London, 2003.

[28] Department of the Environment, Transport and the Regions, Indices of Deprivation, UK Government, London, 2000.

[29] D. Figlio, V. Kolpin, W. Reid, Do states play welfare games? Journal of Urban Economics 46 (1999) 437-454.

[30] P. Fredriksson, D. Millimet, Strategic interaction and the determination of environmental policy across US states, Journal of Urban Economics 51 (2002) 101-122.

[31] P. Fredriksson, D. Millimet, Is there a 'California effect' in US environmental policymaking? Regional Science and Urban Economics 32 (2002) 737-764.

[32] B. Heyndels, J. Vuchelen, Tax mimicking among Belgian municipalities, National Tax Journal 51 (1998) 89-101.

[33] House of Commons, Social and General Statistics Section, Local Elections, UK Parliament, London, 2000-2003. 
[34] H. Kelejian, I. Prucha, A generalised spatial two stage least squares procedure for estimating a spatial autoregressive model with autoregressive disturbances, Journal of Real Estate Finance and Economics 17 (1998) 99-121.

[35] H. Kelejian, D. Robinson, A suggested method of estimation for spatial interdependent models with auto-correlated errors, and an application to a county expenditure model, Papers in Regional Science 72 (1993) 297-312.

[36] H. Ladd, Mimicking of local tax burdens among neighboring counties, Public Finance Quarterly 20 (1992) 450-467.

[37] C. Manski, Identification of endogenous social effects: The reflection problem, Review of Economic Studies 60 (1993) 531-542.

[38] J. Murdoch, M. Rahmatian, M. Thayer, A spatially autoregressive median voter model of recreation expenditures, Public Finance Quarterly 21 (1993) 334-350.

[39] F. Revelli, Spatial patterns in local taxation: Tax mimicking or error mimicking? Applied Economics 33 (2001) 1101-1107.

[40] F. Revelli, Local taxes, national politics and spatial interactions in English district election results, European Journal of Political Economy 18 (2002) 281-299.

[41] F. Revelli, Testing the tax mimicking versus expenditure spill-over hypotheses using English data, Applied Economics 34 (2002) 1723-1731.

[42] F. Revelli, Reaction or interaction? Spatial process identification in multi-tiered government structures, Journal of Urban Economics 53 (2003) 29-53. 
[43] M. Rom, P. Peterson, K. Scheve, Interstate competition and welfare policy, Publius: The Journal of Federalism 28 (1998) 17-37.

[44] L. Saavedra, A model of welfare competition with evidence from AFDC, Journal of Urban Economics 47 (2000) 248-279.

[45] L. Saavedra, Tests for spatial lag dependence based on method of moments estimation, Regional Science and Urban Economics 33 (2003) $27-58$.

[46] C. Schaltegger, D. Kuttel, Exit, voice, and mimicking behavior: evidence from Swiss cantons, Public Choice 113 (2002) 1-23.

[47] M. Shroder, Games the states don't play: Welfare benefits and the theory of fiscal federalism, Review of Economics and Statistics 77 (1995) 183-191.

[48] H-W. Sinn, The New Systems Competition, Blackwell, Oxford, 2003.

[49] M. Smith, State welfare benefits: The political economy of spatial spillovers, unpublished manuscript, Department of Economics, Yale University (1997).

[50] P. Smith, An empirical investigation of interstate AFDC benefit competition, Public Choice 68 (1991) 217-233.

[51] Social Services Inspectorate, Performance Ratings for Social Services in England, Department of Health, London, 2002.

[52] A. Solé Ollé, Electoral accountability and tax mimicking: the effects of electoral margins, coalition government, and ideology, European Journal of Political Economy 19 (2003) 685-713.

[53] W. Wheaton, Decentralized welfare: Will there be underprovision? Journal of Urban Economics 48 (2000) 536-555. 
Table 1 Descriptive statistics: financial year 2000/2001

\begin{tabular}{|c|c|c|c|c|c|c|}
\hline & obs. & mean & std. dev. & $\min$ & $\max$ & source \\
\hline social expenditure p.b. $(£)$ & 146 & 1,012 & 347 & 529 & 2,353 & $\mathrm{C} 1$ \\
\hline grant p.b. $(£)$ & 146 & 839 & 221 & 433 & 1,634 & $\overline{\mathrm{D} 1}$ \\
\hline income (tax base p.c., $£)$ & 146 & 26,520 & 4,134 & 19,188 & 42,354 & $\mathrm{C} 1$ \\
\hline population density & 146 & 24.3 & 26.2 & 0.6 & 133.2 & $\mathrm{C} 1$ \\
\hline population $(, 000)$ & 146 & 338 & 251 & 36 & 1,332 & $\mathrm{C} 1$ \\
\hline percentage old & 146 & 7.0 & 1.5 & 4.3 & 12.7 & $\mathrm{C} 2$ \\
\hline percentage young & 146 & 14.0 & 1.3 & 9.1 & 17.6 & $\mathrm{C} 2$ \\
\hline recipiency ratio & 146 & 0.24 & 0.09 & 0.07 & 0.51 & $\overline{\mathrm{D} 2}$ \\
\hline$\%$ non-domestic properties & 146 & 7.3 & 2.0 & 4.3 & 23.0 & $\mathrm{C} 1$ \\
\hline non-domestic property p.c. $(£)$ & 146 & 806.7 & 915.8 & 321.6 & 10626.9 & $\mathrm{C} 1$ \\
\hline Labour & 84 & & & & & $\mathrm{H} 1$ \\
\hline Conservative & 38 & & & & & $\mathrm{H} 1$ \\
\hline Liberal Democrat \& others & 24 & & & & & $\mathrm{H} 1$ \\
\hline London & 32 & & & & & \\
\hline Metropolitan & 36 & & & & & \\
\hline Unitary authority & 44 & & & & & \\
\hline County & 34 & & & & & \\
\hline
\end{tabular}

Notes

1) p.b. = per beneficiary;

2) p.c. = per capita;

3) tax base per capita $=$ domestic property value per capita;

4) recipiency ratio $=$ income deprived people/taxpayers;

5) C1: CIPFA [23];

6) C2: CIPFA [25];

7) D1: Department of the Environment, Transport and the Regions [26];

8) D2: Department of the Environment, Transport and the Regions [28];

9) H1: House of Commons, Social and General Statistics Section [33]. 
Table 2 Descriptive statistics: financial year 2003/2004

\begin{tabular}{|c|c|c|c|c|c|c|}
\hline & obs. & mean & std. dev. & $\min$ & $\max$ & source \\
\hline social expenditure p.b. $(£)$ & 146 & 1,388 & 465 & 771 & 3,192 & $\mathrm{C} 1$ \\
\hline grant p.b. $(£)$ & 146 & 1,087 & 305 & 626 & 2,026 & D1 \\
\hline income (tax base p.c., $£)$ & 146 & 26,832 & 4,290 & 19,500 & 48,594 & $\mathrm{C} 1$ \\
\hline population density & 146 & 24.2 & 26.3 & 0.6 & 128.5 & C1 \\
\hline population $(, 000)$ & 146 & 336 & 253 & 35 & 1,331 & $\mathrm{C} 1$ \\
\hline percentage old & 146 & 7.0 & 1.5 & 4.3 & 12.7 & $\overline{\mathrm{C} 2}$ \\
\hline percentage young & 146 & 14.0 & 1.2 & 9.1 & 17.6 & $\mathrm{C} 2$ \\
\hline recipiency ratio & 146 & 0.24 & 0.09 & 0.07 & 0.48 & $\overline{\mathrm{D} 2}$ \\
\hline$\%$ non-domestic properties & 146 & 7.1 & 1.9 & 4.2 & 22.8 & $\mathrm{C} 1$ \\
\hline non-domestic property p.c. $(£)$ & 146 & 856.1 & 1098.8 & 332.6 & 13058.9 & $\mathrm{C} 1$ \\
\hline Labour & 78 & & & & & $\mathrm{H} 1$ \\
\hline Conservative & 45 & & & & & H1 \\
\hline Liberal Democrat \& others & 23 & & & & & $\mathrm{H} 1$ \\
\hline London & 32 & & & & & \\
\hline Metropolitan & 36 & & & & & \\
\hline Unitary authority & 44 & & & & & \\
\hline County & 34 & & & & & \\
\hline
\end{tabular}

Notes

1) p.b. = per beneficiary;

2) p.c. = per capita;

3) tax base per capita $=$ domestic property value per capita;

4) recipiency ratio $=$ income deprived people/taxpayers;

5) C1: CIPFA [24];

6) C2: CIPFA [25];

7) D1: Department of the Environment, Transport and the Regions [27];

8) D2: Department of the Environment, Transport and the Regions [28];

9) H1: House of Commons, Social and General Statistics Section [33]. 
Table 3 Spatial model estimation: financial year 2000/2001

\begin{tabular}{|c|c|c|c|c|}
\hline & 1 & 2 & 3 & 4 \\
\hline & SAR & SAR & SAR & SARMA \\
\hline & OLS & $\mathrm{ML}$ & 2 SLS & $\mathrm{ML}$ \\
\hline constant & $0.704(0.68)$ & $0.602(0.61)$ & $0.745(0.72)$ & $0.471(0.98)$ \\
\hline grant & $0.577(6.20)$ & $0.614(7.04)$ & $0.568(6.12)$ & $0.624(6.74)$ \\
\hline income & $0.219(1.62)$ & $0.233(1.80)$ & $0.211(1.56)$ & $0.212(1.45)$ \\
\hline recipiency ratio & $-0.210(-4.21)$ & $-0.148(-4.14)$ & $-0.213(-4.29)$ & $-0.145(-3.98)$ \\
\hline population density & $0.029(2.11)$ & $0.028(2.11)$ & $0.029(2.10)$ & $0.026(1.87)$ \\
\hline population & $-0.022(-0.95)$ & $-0.022(-0.98)$ & $-0.023(-1.00)$ & $-0.024(-1.02)$ \\
\hline$\%$ old & $-0.067(-1.37)$ & $-0.074(-1.58)$ & $-0.064(-1.32)$ & $-0.081(-1.54)$ \\
\hline$\%$ young & $-0.102(-0.83)$ & $-0.058(-0.51)$ & $-0.108(-0.88)$ & $-0.050(-0.43)$ \\
\hline$\alpha_{1}$ & $0.195(3.07)$ & $0.185(3.13)$ & $0.208(3.24)$ & $0.197(2.77)$ \\
\hline$\rho$ & & & & $-0.105(-0.29)$ \\
\hline Moran I test & 2.12 & & & \\
\hline robust LM test $\alpha_{1}$ & 7.96 & & & \\
\hline robust LM test $\rho$ & 0.01 & & & \\
\hline LR test & 9.42 & & & \\
\hline authority type dummies & yes & yes & yes & yes \\
\hline observations & 146 & 146 & 146 & 146 \\
\hline
\end{tabular}

Notes

1) dependent variable: $\log$ (social spending per beneficiary);

2) $t$ statistics in parentheses;

3) $\alpha_{1}=$ auto-regressive coefficient on spatially lagged dependent variable: equation (10);

4) $\rho=$ coefficient on moving average process in the error term: equation (11);

5) the Moran I test is distributed as a standard normal $z(0,1)$;

6) the LM and LR tests are distributed as $\chi_{(1)}^{2}$. 
Table 4 Spatial model estimation: financial year 2003/2004

\begin{tabular}{|c|c|c|c|c|}
\hline & 1 & 2 & 3 & 4 \\
\hline & SAR & SAR & SAR & SARMA \\
\hline & OLS & $\mathrm{ML}$ & 2 SLS & $\mathrm{ML}$ \\
\hline constant & $0.272(0.28)$ & $0.284(0.31)$ & $0.433(0.44)$ & $0.151(0.14)$ \\
\hline grant & $0.769(7.57)$ & $0.772(7.89)$ & $0.736(7.09)$ & $0.779(8.10)$ \\
\hline income & $0.230(1.94)$ & $0.231(2.06)$ & $0.226(1.93)$ & $0.230(1.94)$ \\
\hline recipiency ratio & $-0.113(-2.03)$ & $-0.114(-2.17)$ & $-0.130(-2.28)$ & $-0.103(-1.91)$ \\
\hline population density & $0.017(1.31)$ & $0.017(1.40)$ & $0.018(1.39)$ & $0.016(1.25)$ \\
\hline population & $-0.025(-1.15)$ & $-0.025(-1.20)$ & $-0.027(-1.25)$ & $-0.028(-1.32)$ \\
\hline$\%$ old & $0.033(0.72)$ & $0.032(0.75)$ & $0.031(0.70)$ & $0.030(0.72)$ \\
\hline$\%$ young & $-0.127(-1.12)$ & $-0.127(-1.18)$ & $-0.137(-1.21)$ & $-0.110(-0.93)$ \\
\hline$\alpha_{1}$ & $0.081(1.40)$ & $0.077(1.42)$ & $0.098(1.67)$ & $0.092(1.64)$ \\
\hline$\rho$ & & & & $-0.180(-0.93)$ \\
\hline Moran I test & 0.37 & & & \\
\hline robust LM test $\alpha_{1}$ & 2.58 & & & \\
\hline robust LM test $\rho$ & 0.65 & & & \\
\hline LR test & 2.01 & & & \\
\hline authority type dummies & yes & yes & yes & yes \\
\hline observations & 146 & 146 & 146 & 146 \\
\hline
\end{tabular}

Notes

1) dependent variable: $\log$ (social spending per beneficiary);

2) $t$ statistics in parentheses;

3) $\alpha_{1}=$ auto-regressive coefficient on spatially lagged dependent variable: equation (10);

4) $\rho=$ coefficient on moving average process in the error term: equation (11);

$5)$ the Moran I test is distributed as a standard normal $z(0,1)$;

6) the LM and LR tests are distributed as $\chi_{(1)}^{2}$. 
Table 5 Spatial model estimation: financial years 2000/01 to 2003/04

\begin{tabular}{lccc}
\hline & 1 & 2 & 3 \\
\hline & SAR & SAR & SAR \\
\hline grant & $0.796(15.38)$ & $0.811(15.59)$ & $0.821(15.40)$ \\
\hline income & $-0.037(-0.75)$ & $-0.048(-0.93)$ & $-0.045(-0.87)$ \\
\hline recipiency ratio & $-0.176(-6.86)$ & $-0.171(-6.65)$ & $-0.171(-6.54)$ \\
\hline population density & $0.023(3.57)$ & $0.023(3.51)$ & $0.023(3.52)$ \\
\hline population & $-0.027(-2.47)$ & $-0.027(-2.44)$ & $-0.026(2.32)$ \\
\hline$\%$ old & $-0.039(-1.76)$ & $-0.038(-1.71)$ & $-0.042(1.83)$ \\
\hline$\%$ young & $-0.113(-2.08)$ & $-0.108(-1.94)$ & $-0.104(1.85)$ \\
\hline$\alpha_{1}$ & $0.134(4.79)$ & $0.153(5.31)$ & $0.140(4.38)$ \\
\hline$\alpha_{1} \times D(S S P R)$ & & $-0.086(-2.62)$ & $-0.090(2.75)$ \\
\hline LR test & & 6.77 & \\
\hline time dummies & yes & yes & yes \\
\hline authority type dummies & yes & yes & yes \\
\hline observations & 584 & 584 & 584
\end{tabular}

Notes

1) dependent variable: $\log$ (social spending per beneficiary);

2) $t$ statistics in parentheses;

3) $\alpha_{1}=$ auto-regressive coefficient on spatially lagged dependent variable: equation (10);

4) $D(S S P R)$ : dummy variable equal to 1 in financial year $2003 / 2004,0$ otherwise;

5) the LR test is distributed as $\chi_{(1)}^{2}$; 


\section{CESifo Working Paper Series}

(for full list see www.cesifo.de)

1209 Stephan Klasen and Thorsten Nestmann, Population, Population Density, and Technological Change, June 2004

1210 Wolfgang Ochel, Welfare Time Limits in the United States - Experiences with a New Welfare-to-Work Approach, June 2004

1211 Luis H. R. Alvarez and Erkki Koskela, Taxation and Rotation Age under Stochastic Forest Stand Value, June 2004

1212 Bernard M. S. van Praag, The Connexion Between Old and New Approaches to Financial Satisfaction, June 2004

1213 Hendrik Hakenes and Martin Peitz, Selling Reputation When Going out of Business, June 2004

1214 Heikki Oksanen, Public Pensions in the National Accounts and Public Finance Targets, June 2004

1215 Ernst Fehr, Alexander Klein, and Klaus M. Schmidt, Contracts, Fairness, and Incentives, June 2004

1216 Amihai Glazer, Vesa Kanniainen, and Panu Poutvaara, Initial Luck, Status-Seeking and Snowballs Lead to Corporate Success and Failure, June 2004

1217 Bum J. Kim and Harris Schlesinger, Adverse Selection in an Insurance Market with Government-Guaranteed Subsistence Levels, June 2004

1218 Armin Falk, Charitable Giving as a Gift Exchange - Evidence from a Field Experiment, June 2004

1219 Rainer Niemann, Asymmetric Taxation and Cross-Border Investment Decisions, June 2004

1220 Christian Holzner, Volker Meier, and Martin Werding, Time Limits on Welfare Use under Involuntary Unemployment, June 2004

1221 Michiel Evers, Ruud A. de Mooij, and Herman R. J. Vollebergh, Tax Competition under Minimum Rates: The Case of European Diesel Excises, June 2004

1222 S. Brock Blomberg and Gregory D. Hess, How Much Does Violence Tax Trade?, June 2004

1223 Josse Delfgaauw and Robert Dur, Incentives and Workers' Motivation in the Public Sector, June 2004 
1224 Paul De Grauwe and Cláudia Costa Storti, The Effects of Monetary Policy: A MetaAnalysis, June 2004

1225 Volker Grossmann, How to Promote R\&D-based Growth? Public Education Expenditure on Scientists and Engineers versus R\&D Subsidies, June 2004

1226 Bart Cockx and Jean Ries, The Exhaustion of Unemployment Benefits in Belgium. Does it Enhance the Probability of Employment?, June 2004

1227 Bertil Holmlund, Sickness Absence and Search Unemployment, June 2004

1228 Klaas J. Beniers and Robert Dur, Politicians' Motivation, Political Culture, and Electoral Competition, June 2004

1229 M. Hashem Pesaran, General Diagnostic Tests for Cross Section Dependence in Panels, July 2004

1230 Wladimir Raymond, Pierre Mohnen, Franz Palm, and Sybrand Schim van der Loeff, An Empirically-Based Taxonomy of Dutch Manufacturing: Innovation Policy Implications, July 2004

1231 Stefan Homburg, A New Approach to Optimal Commodity Taxation, July 2004

1232 Lorenzo Cappellari and Stephen P. Jenkins, Modelling Low Pay Transition Probabilities, Accounting for Panel Attrition, Non-Response, and Initial Conditions, July 2004

1233 Cheng Hsiao and M. Hashem Pesaran, Random Coefficient Panel Data Models, July 2004

1234 Frederick van der Ploeg, The Welfare State, Redistribution and the Economy, Reciprocal Altruism, Consumer Rivalry and Second Best, July 2004

1235 Thomas Fuchs and Ludger Woessmann, What Accounts for International Differences in Student Performance? A Re-Examination Using PISA Data, July 2004

1236 Pascalis Raimondos-Møller and Alan D. Woodland, Measuring Tax Efficiency: A Tax Optimality Index, July 2004

1237 M. Hashem Pesaran, Davide Pettenuzzo, and Allan Timmermann, Forecasting Time Series Subject to Multiple Structural Breaks, July 2004

1238 Panu Poutvaara and Andreas Wagener, The Invisible Hand Plays Dice: Eventualities in Religious Markets, July 2004

1239 Eckhard Janeba, Moral Federalism, July 2004

1240 Robert S. Chirinko, Steven M. Fazzari, and Andrew P. Meyer, That Elusive Elasticity: A Long-Panel Approach to Estimating the Capital-Labor Substitution Elasticity, July 2004 
1241 Hans Jarle Kind, Karen Helene Midelfart, Guttorm Schjelderup, Corporate Tax Systems, Multinational Enterprises, and Economic Integration, July 2004

1242 Vankatesh Bala and Ngo Van Long, International Trade and Cultural Diversity: A Model of Preference Selection, July 2004

1243 Wolfgang Eggert and Alfons J. Weichenrieder, On the Economics of Bottle Deposits, July 2004

1244 Sören Blomquist and Vidar Christiansen, Taxation and Heterogeneous Preferences, July 2004

1245 Rafael Lalive and Alois Stutzer, Approval of Equal Rights and Gender Differences in Well-Being, July 2004

1246 Paolo M. Panteghini, Wide vs. Narrow Tax Bases under Optimal Investment Timing, July 2004

1247 Marika Karanassou, Hector Sala, and Dennis J. Snower, Unemployment in the European Union: Institutions, Prices, and Growth, July 2004

1248 Engin Dalgic and Ngo Van Long, Corrupt Local Government as Resource Farmers: The Helping Hand and the Grabbing Hand, July 2004

1249 Francesco Giavazzi and Guido Tabellini, Economic and Political Liberalizations, July 2004

1250 Yin-Wong Cheung and Jude Yuen, An Output Perspective on a Northeast Asia Currency Union, August 2004

1251 Ralf Elsas, Frank Heinemann, and Marcel Tyrell, Multiple but Asymmetric Bank Financing: The Case of Relationship Lending, August 2004

1252 Steinar Holden, Wage Formation under Low Inflation, August 2004

1253 Ngo Van Long and Gerhard Sorger, Insecure Property Rights and Growth: The Roles of Appropriation Costs, Wealth Effects, and Heterogeneity, August 2004

1254 Klaus Wälde and Pia Weiß, International Competition, Slim Firms and Wage Inequality, August 2004

1255 Jeremy S. S. Edwards and Alfons J. Weichenrieder, How Weak is the Weakest-Link Principle? On the Measurement of Firm Owners’ Control Rights, August 2004

1256 Guido Tabellini, The Role of the State in Economic Development, August 2004

1257 François Larmande and Jean-Pierre Ponssard, EVA and the Controllability-congruence Trade-off: An Empirical Investigation, August 2004 
1258 Vesa Kanniainen and Jenni Pääkkönen, Anonymous Money, Moral Sentiments and Welfare, August 2004

1259 Panu Poutvaara and Andreas Wagener, Why is the Public Sector More Labor-Intensive? A Distortionary Tax Argument, August 2004

1260 Lars P. Feld and Stefan Voigt, Making Judges Independent - Some Proposals Regarding the Judiciary, August 2004

1261 Joop Hartog, Hans van Ophem, and Simona Maria Bajdechi, How Risky is Investment in Human Capital?, August 2004

1262 Thomas Eichner and Rüdiger Pethig, Efficient Nonanthropocentric Nature Protection, August 2004

1263 David-Jan Jansen and Jakob de Haan, Look Who's Talking: ECB Communication during the First Years of EMU, August 2004

1264 David F. Bradford, The X Tax in the World Economy, August 2004

1265 Hans-Werner Sinn, Migration, Social Standards and Replacement Incomes. How to Protect Low-income Workers in the Industrialized Countries against the Forces of Globalization and Market Integration, August 2004

1266 Wolfgang Leininger, Fending off one Means Fending off all: Evolutionary Stability in Submodular Games, August 2004

1267 Antoine Bommier and Bertrand Villeneuve, Risk Aversion and the Value of Risk to Life, September 2004

1268 Harrie A. A. Verbon and Lex Meijdam, Too Many Migrants, Too Few Services: A Model of Decision-making on Immigration and Integration with Cultural Distance, September 2004

1269 Thomas Eichner and Rüdiger Pethig, Economic Land Use, Ecosystem Services and Microfounded Species Dynamics, September 2004

1270 Federico Revelli, Performance Rating and Yardstick Competition in Social Service Provision, September 2004 